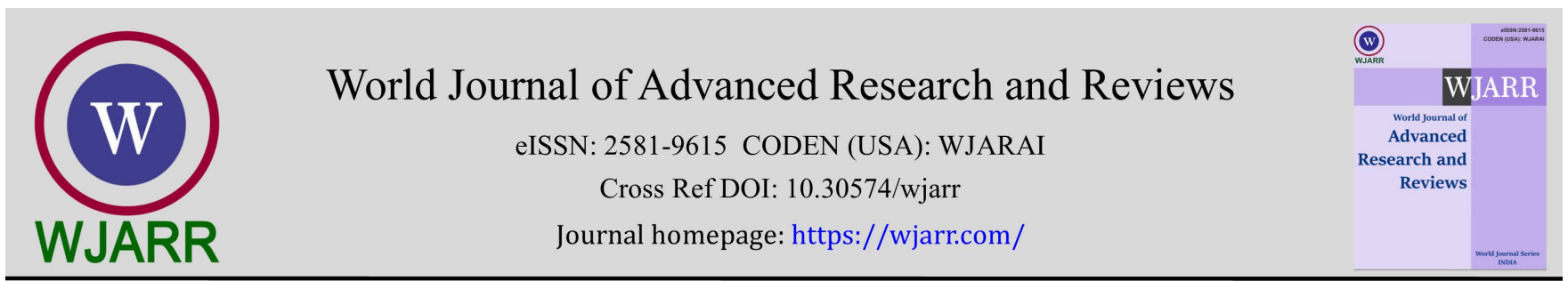

(RESEARCH ARTICLE)

Check for updates

\title{
Effect of storage of botanical extracts and modified Panchagavya against radial growth of Fusarium oxysporum
}

\author{
David Kamei ${ }^{1}$, Archana U Singh 2,* and Gaichui Gangmei ${ }^{3}$ \\ ${ }^{1}$ KVK-Senapati, Manipur, ICAR. \\ 2 Dept. of Nematology, ICAR-IARI, New Delhi. \\ ${ }^{3}$ Dept. of Agri. Govt. of Manipur.
}

World Journal of Advanced Research and Reviews, 2022, 13(02), 219-224

Publication history: Received on 27December 2021; revised on 07 February 2022; accepted on 09 February 2022

Article DOI: https://doi.org/10.30574/wjarr.2022.13.2.0110

\begin{abstract}
Storage of botanical extracts reduced the effectiveness on the radial growth of Fusarium oxysporum but enhances in the case of Modified Panchagavya (MPG). The mean radial growth of $F$. oxysporum at $0,2,4,6,8$ and 10 days of storage were $38.83,42.68,46.61,51.07,56.04$ and 60.73 per cent respectively. Garlic extract showed no growth at 0 day of storage but $10.00 \mathrm{~mm}$ was observed at two days of storage period which increased with an increase in storage time and the highest growth of $52.50 \mathrm{~mm}$ with 69.84 per cent radial growth inhibition at 10 days of storage period. In case of MPG maximum radial growth of fungal mycelium $(57.33 \mathrm{~mm})$ was observed at 0 day storage time and it gradually decreased with increase in storage time where highest growth inhibition was observed at 10 days of storage (42.50 mm) with 52.77 per cent radial growth inhibition of $F$. oxysporum over the untreated control.
\end{abstract}

Keywords: Botanicals; Fungus; Extracts; Chilli; Wilt; Fusarium oxysporum

\section{Introduction}

Chilli is the most popular spices known to suffer from various diseases caused by fungi, bacteria, virus and nematodes which reduce the potential yield of the crop. Among various diseases Chilli wilt caused by fungal pathogen Fusarium species is a serious one. The symptoms appear as yellowing and wilting of foliage, starting from the lower leaves and the woody tissue of the stem turns brown causing total or partial killing of the standing crops. The fungus is soil borne, initially infect the root system and later invades the vascular system of the plant causing discolouration. [1] Work on the incidence and severity of Pepper wilt caused by Fusarium oxysporum f. sp. redolens and Fusarium wilt of chilli caused by Fusarium annum L and reported that the disease was characterized by inward and upward rolling of the leaves and wilting of the plant. In Manipur Fusarium wilt disease of Chilli was most prominent and occurs in severe forms. The common disease control method is the application of chemical fungicides which is known for causing ill effect on nature environment, human and animal health. Keeping in view of this the present work is taken up during the Kharif 2019-20 based on the use of indigenous botanicals of Manipur and natural products Modified Panchagavya (MPG) for managing this important disease.

\footnotetext{
*Corresponding author: Archana U Singh

Division of Nematology, ICAR-IARI. New Delhi-12
}

Copyright $(2022$ Author(s) retain the copyright of this article. This article is published under the terms of the Creative Commons Attribution Liscense 4.0. 


\section{Material and methods}

\subsection{Isolation, purification and identification of pathogen:}

Chilli plants showing typical wilts symptoms was collected from the farmer's field and brought in the plant pathology laboratory of KVK-Senapati, Manipur for isolation. A discoloured vascular tissue from collar and root region of infected plant was cut into small pieces of $1 \mathrm{~mm}$ bits and surface sterilized with $1 \%$ sodium hypochloride (NaOCl) solution. This is followed by three time's serial washing in sterile water. These sterilized bits was then placed aseptically on Potato dextrose agar (PDA) medium in sterilized petriplates and incubated at $25 \pm 1^{\circ} \mathrm{C}$ for five days. The observation for the development of the fungus was made at 24 hours interval and purification of the fungal pathogen was done by single hyphal tip culture method.

\subsection{Preparation of Botanical extracts}

The aqueous botanical extracts of five different indigenous plants of Manipur viz.Wild sage, Darrek, Nongmangkha, Ginger and Garlic was collected and washed with tap water followed by sterile water and shade dry for 24 hours to remove the excess moisture. The plant material was weighed and crushed with equal quantity of sterile water i.e.,1 $\mathrm{g}$ per $1 \mathrm{ml}$ sterile water $(1: 1 \mathrm{w} / \mathrm{v})$ with the help of sterilized mortar and pestle. The botanical extracts was filtered in double layer muslin cloth. This formed the standard $100 \%$ botanical extract solution used in the experiments.

\subsection{Preparation of Modified Panchagavya (MPG)}

In Sanskrit Panchagavya means combination of five products procured from cow (Milk, curd, ghee, dung and urine). It is an ancient ritualistic practice prescribed in Hindu scripture to administer Panchagavya to human beings under many conditions of ill health, convalescence and as spiritual purifying agent [2].

In the case of our present investigation a modified panchagavya (MPG) was prepared by following method [3]. For preparing 1 litre of MPG slurry the following ingredients was required Table 1.

Table 1 Ingredients require for preparation of 1 litre of Modified Panchagavya (MPG)

\begin{tabular}{|l|l|l|}
\hline Sl. No. & Ingredients & Quantity \\
\hline 1. & Cow ghee & $20 \mathrm{ml}$ \\
\hline 2. & Curd & $50 \mathrm{ml}$ \\
\hline 3. & Milk & $50 \mathrm{ml}$ \\
\hline 4 & Cow urine & $480 \mathrm{ml}$ \\
\hline 5. & Cow dung & $400 \mathrm{~g}$ \\
\hline 6. & common salt & $20 \mathrm{~g}$ \\
\hline 7. & Backing yeast & $10 \mathrm{~g}$ \\
\hline
\end{tabular}

All the above listed ingredients was thoroughly mixed and allowed to ferment for 10 days with twice stirring daily. This crude fermented product was diluted 10 times with sterile water and this preparation is now taken to be as 100 per cent standard solution. The diluted preparation was filtered through double layers of muslin cloth and filtrate was used in the experiment at any desired level of concentration. The $\mathrm{pH}$ of the mixture was recorded on zero days and at ten days of the incubation of the mixture.

Studies on the effect of storage periods of botanical extracts and MPG on the radial growth of Fusarium oxysporum (invitro) by Poison Food Technique [4] was carried out. The concentration of botanical extracts and MPG was adjusted uniformly at $15 \%$ concentration as given in Table 2 . 
Table 2 Botanicals extracts, MPG and their per cent concentration used in the experiment

\begin{tabular}{|l|l|l|l|l|l|}
\hline Sl.No. & Common name & $\begin{array}{l}\text { Scientific/trade } \\
\text { name }\end{array}$ & $\begin{array}{l}\text { Part } \\
\text { used }\end{array}$ & $\begin{array}{l}\text { \% conc. } \\
\text { used }\end{array}$ & Composition \\
\hline 1. & Wild sage & Lantana camara & leaves & 15 & $\begin{array}{l}\text { Lantadene A and lancamarone (Thakur \& } \\
\text { Pandey, 1998) }\end{array}$ \\
\hline 2. & Darrek & Melia azediracha & leaves & 15 & $\begin{array}{l}\text { Cis and trans-3, 5-diethyl-1, 2 4-trithiolanes } \\
\text { (Azadirachtin), (Mubarak \&Kulatillek, 1990) }\end{array}$ \\
\hline 3. & Nongmangkha & $\begin{array}{l}\text { Phlogacanthus } \\
\text { thyrsiflorus }\end{array}$ & leaves & 15 & $\begin{array}{l}\text { Phenolic, tannin, saponin, terpinoid, glycoside, } \\
\text { (Kamei, D. 2019) }\end{array}$ \\
\hline 4. & Ginger & $\begin{array}{l}\text { Zingiber officinale } \\
\text { (Khizome }\end{array}$ & 15 & $\begin{array}{l}\text { Gingerenon A } \\
\text { (Kikuzakiet al., 1991) }\end{array}$ \\
\hline 6. & $\begin{array}{l}\text { Garlic } \\
\text { Panchagavya }\end{array}$ & Allium sativum & bulb & 15 & Diallyl disulphide (Mazza et al. 1992) \\
\hline
\end{tabular}

The influence of storage of five different botanicals extracts and MPG was stored for different time periods of $0,2,4,6$, 8 and 10 days at room temperature. For this experiment the standard botanical extracts and MPG was calibrated at $15 \%$ concentration and aseptically added to $50 \mathrm{ml}$ sterilized molten potato dextrose agar (PDA) medium and gently shaken in circular motion for evenly distribution. $15 \mathrm{ml}$ of these poisoned media were aseptically dispensed in sterilized $9 \mathrm{~cm}$ diameter petriplates and allowed to solidify. Plates containing the medium without treatment served as control. Then $5 \mathrm{~mm}$ mycelial disc of 5 days old pathogen culture were aseptically inoculated at the centre of the plates. Each treatment was replicated four times. The plates was incubated at $25 \pm 1^{\circ} \mathrm{C}$ in BOD incubator and growth of the test fungus was measured every 24 hours of incubation till the fungus in the control plates covered the whole surface of the plate and growth inhibition percentage over control was calculated by the following method [5].

$$
\mathrm{I}=\frac{C-T}{C} \times 100
$$

where I - inhibition of mycelia growth over control

C - Mycelial growth in control

$\mathrm{T}$ - Mycelial growth in treatment

\section{Results}

The data presented in Table 3 revealed that maximum radial growth of test fungus was observed in all botanicals stored for 10 days. The growth of test fungus increased with increase in storage time and found to have significant differences among the different storage periods in all the plants extracts, i.e. all botanical extracts showed a gradual decrease in their efficacy in inhibiting the radial growth of $F$. oxysporum with longer storage duration. However, in case of MPG its efficiency in inhibiting the radial growth of fungus gradually increased with increase in their storage periods within the time frame of present investigation. At $0,2,4,6,8$ and 10 days storage period average the radial growth of $F$. oxysporum in Garlic extracts was $0.00,10.00,22.00,33.33,45.00$ and $52.50 \mathrm{~mm}$ respectively. This was followed by Darrek (8.66, $19.33,28.83,37.00,45.66$ and $55.50 \mathrm{~mm})$ in case of Nongmangkha $(36.33,39.33,43.00,46.83,51.16$ and $56.60 \mathrm{~mm})$ respectively. Similar trend was observed in all the other botanical extracts. In case of natural product (MPG) mixture, maximum radial growth of fungal mycelium $(57.33 \mathrm{~mm})$ was observed at 0 day storage time and radial growth of mycelium gradually decreased with increase in storage time whereas at 2, 4, 6, 8 and 10 days of storage, the growth of fungus was $51.83 \mathrm{~mm}, 45.83 \mathrm{~mm}, 44.33 \mathrm{~mm}, 43.66 \mathrm{~mm}$ and $42.50 \mathrm{~mm}$ respectively. However in Control the average radial growth at $0,2,4,6,8$ and 10 days of storage remained constant at $90.00 \mathrm{~mm}$. 
Table 3 Effect of storage periods of botanical extracts and MPG on radial growth of Fusarium oxysporum in-vitro

\begin{tabular}{|c|c|c|c|c|c|c|c|c|}
\hline \multirow[t]{2}{*}{ Treatment (T) } & \multirow[t]{2}{*}{$\begin{array}{l}\text { Conc.\% } \\
\text { (C) }\end{array}$} & \multicolumn{6}{|c|}{$\begin{array}{l}\text { Average radial growth of mycelium }(\mathrm{mm}) * \text { at different storage } \\
\text { periods }(\mathrm{P})\end{array}$} & \multirow[t]{2}{*}{ Mean } \\
\hline & & 0 days & 2days & 4 days & 6 days & 8 days & 10 days & \\
\hline $\begin{array}{l}\text { Wild sage } \\
\text { (Lantana camara) }\end{array}$ & 15 & $\begin{array}{c}38.5 \\
(6.24)\end{array}$ & $\begin{array}{r}44.16 \\
(6.68)\end{array}$ & $\begin{array}{l}50.66 \\
(7.15)\end{array}$ & $\begin{array}{l}58.00 \\
(7.64)\end{array}$ & $\begin{array}{l}66.66 \\
(8.19)\end{array}$ & $\begin{array}{l}76.33 \\
(8.76)\end{array}$ & $\begin{array}{l}55.71 \\
(7.49)\end{array}$ \\
\hline $\begin{array}{l}\text { Darrek } \\
(\text { Melia azediracha })\end{array}$ & 15 & $\begin{array}{c}8.66 \\
(3.02)\end{array}$ & $\begin{array}{l}19.33 \\
(4.45)\end{array}$ & $\begin{array}{l}28.83 \\
(5.41)\end{array}$ & $\begin{array}{l}37.00 \\
(6.12)\end{array}$ & $\begin{array}{l}45.66 \\
(6.79)\end{array}$ & $\begin{array}{l}55.50 \\
(7.46)\end{array}$ & $\begin{array}{l}32.49 \\
(5.74)\end{array}$ \\
\hline $\begin{array}{l}\text { Nongmangkha } \\
\text { (Phloogacanthus } \\
\text { thyrsiflorus) }\end{array}$ & 15 & $\begin{array}{l}36.33 \\
(6.06)\end{array}$ & $\begin{array}{l}39.33 \\
(6.31)\end{array}$ & $\begin{array}{l}43.00 \\
(6.59)\end{array}$ & $\begin{array}{l}46.83 \\
(6.87)\end{array}$ & $\begin{array}{l}51.16 \\
(7.17)\end{array}$ & $\begin{array}{l}56.50 \\
(7.54)\end{array}$ & $\begin{array}{l}45.52 \\
(6.78)\end{array}$ \\
\hline $\begin{array}{l}\text { Ginger } \\
\text { (Zingiber officinale) }\end{array}$ & 15 & $\begin{array}{l}41.00 \\
(6.44)\end{array}$ & $\begin{array}{l}44.16 \\
(6.68)\end{array}$ & $\begin{array}{l}46.00 \\
(6.81)\end{array}$ & $\begin{array}{l}48.00 \\
(6.96)\end{array}$ & $\begin{array}{l}50.16 \\
(7.11)\end{array}$ & $\begin{array}{l}51.83 \\
(7.23)\end{array}$ & $\begin{array}{l}46.85 \\
(6.88)\end{array}$ \\
\hline $\begin{array}{l}\text { Garlic } \\
\text { (Allium sativum) }\end{array}$ & 15 & $\begin{array}{c}0 ; 00 \\
(0.70)\end{array}$ & $\begin{array}{l}10.00 \\
(3.24)\end{array}$ & $\begin{array}{l}22.00 \\
(4.74)\end{array}$ & $\begin{array}{l}33.33 \\
(5.81)\end{array}$ & $\begin{array}{l}45.00 \\
(6.74)\end{array}$ & $\begin{array}{l}52.50 \\
(7.28)\end{array}$ & $\begin{array}{l}27.13 \\
(5.25)\end{array}$ \\
\hline $\begin{array}{l}\text { Modified Panchagavya } \\
\text { (MPG) }\end{array}$ & 15 & $\begin{array}{l}57.33 \\
(7.60)\end{array}$ & $\begin{array}{l}51.83 \\
(7.23)\end{array}$ & $\begin{array}{l}45.83 \\
(6.80)\end{array}$ & $\begin{array}{l}44.33 \\
(6.69)\end{array}$ & $\begin{array}{l}43.88 \\
(6.64)\end{array}$ & $\begin{array}{l}42.50 \\
(6.65)\end{array}$ & $\begin{array}{l}47.58 \\
(6.93)\end{array}$ \\
\hline Control & - & $\begin{array}{l}90.00 \\
(9.51)\end{array}$ & $\begin{array}{l}90.00 \\
(9.51)\end{array}$ & $\begin{array}{l}90.00 \\
(9.51)\end{array}$ & $\begin{array}{l}90.00 \\
(9.51)\end{array}$ & $\begin{array}{l}90.00 \\
(9.51)\end{array}$ & $\begin{array}{l}90.00 \\
(9.51)\end{array}$ & $\begin{array}{l}90.00 \\
(9.51)\end{array}$ \\
\hline Mean & - & 38.83 & 42.68 & 46.61 & 51.07 & 56.04 & 60.73 & - \\
\hline $\mathrm{SE} \pm \mathrm{d}$ & - & 0.174 & 0.157 & 0.152 & 0.092 & 0.068 & 0.074 & 0.25 \\
\hline C.D. $(0.05)$ & - & 0.379 & 0.342 & 0.330 & 0.200 & 0.150 & 0.162 & 0.541 \\
\hline
\end{tabular}

Figures in parentheses are square root transformed values $(\sqrt{x}+0.5)$

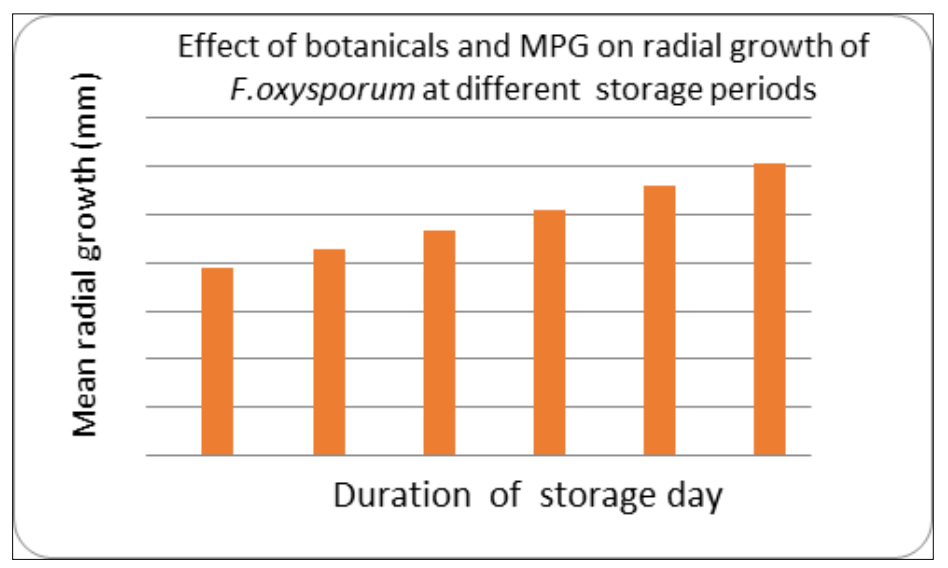

Figure 1 Botanicals and MPG and mean radial growth of $F$. oxysporum on different storage period

Data presented in Table 4 indicated that maximum growth inhibition per cent of $F$. oxysporum over control was observed in all the botanical extracts at 0 day of storage. Growth inhibition per cent over control decreased with increase in the storage period in all the botanical extracts treated plates whereas in case of natural product (MPG) was observed that its inhibition per cent over control increased with increase in storage time period. Minimum growth inhibition per cent over control was observed in all botanical extracts stored for 10 days whereas in contrary maximum growth inhibition was observed in MPG of 10 days of storage as compared to 0 days of storage. Garlic extracts recorded complete growth 
inhibition at 0 day storage period and growth inhibition percentage decreased at 2, 4, 6, 8 and 10 days of storage was 88.88, 75.55, 62.96, 50.00 and 41.66 per cent respectively followed by Darrek $(90.37,78.52,67.96,58.88,49.26$ and 38.33), Nongmangkha (59.63, 56.30, 52.22, 47.96, 43.15 and 37.22), Wild sage (57.22, 50.93, 43.71, 35.55, 25.93 and 15.18), Ginger (54.44, 50.93, 48.88, 46.66, 44.26 and 42.11) respectively in 0,2 , $4,6,8$ and 10 days of storage over control. In case of MPG the per cent growth inhibition over control was 36.30, 42.41, $50.92,50.92,50.74,51.48$ and 52.77 per cent respectively in $0,2,4,6,8$ and 10 days of storage period.

Table 4 Effect of storage periods of botanicals and MPG on radial growth inhibition per cent of F. oxysporum

\begin{tabular}{|c|c|c|c|c|c|c|c|c|}
\hline \multirow{3}{*}{ Treatment ( $\mathrm{T})$} & \multirow{3}{*}{ Conc.\% (C) } & \multicolumn{6}{|c|}{ Radial growth inhibition percentage over control* } & \multirow{3}{*}{ Mean } \\
\hline & & \multicolumn{6}{|c|}{ Storage period (P) } & \\
\hline & & 0 days & 2days & 4 days & 6 days & 8 days & 10 days & \\
\hline $\begin{array}{l}\text { Wild sage } \\
\text { (Lantana camara) }\end{array}$ & 15 & 57.22 & 50.93 & 43.71 & 35.55 & 25.93 & 15.18 & 38.08 \\
\hline $\begin{array}{l}\text { Darrek } \\
\text { (Melia azediracha) }\end{array}$ & 15 & 90.37 & 78.52 & 67.96 & 58.88 & 49.26 & 38.33 & 63.88 \\
\hline $\begin{array}{l}\text { Nongmangkha } \\
\text { (Phlogacanthus } \\
\text { thyrsiflorus) }\end{array}$ & 15 & 59.63 & 56.30 & 52.22 & 47.96 & 43.15 & 37.22 & 54.44 \\
\hline $\begin{array}{l}\text { Ginger } \\
\text { (Zingiber officinale) }\end{array}$ & 15 & 54.44 & 50.93 & 48.88 & 46.66 & 44.26 & 42.11 & 47.88 \\
\hline $\begin{array}{l}\text { Garlic } \\
\text { (Allium sativum) }\end{array}$ & 15 & 100.00 & 88.88 & 75.55 & 62.96 & 50.00 & 41.66 & 69.84 \\
\hline $\begin{array}{l}\text { MPG } \\
\text { (Modified Panchagavya) }\end{array}$ & 15 & 36.30 & 42.41 & 50.92 & 50.74 & 51.48 & 52.77 & 47.43 \\
\hline Control & - & 0.00 & 0.00 & 0.00 & 0.00 & 0.00 & 0.00 & 0.00 \\
\hline
\end{tabular}

\section{Discussion}

Table 3 indicated that all the five botanicals showed decrease in their storage period efficacy in inhibiting mycelia growth of Fusarium oxysporum with increase in their storage period. Among the botanicals Garlic showed no radial growth when treated immediately after preparation and radial growth increased gradually with increase in storage period (52.50 $\mathrm{mm})$ at 10 days of storage. The results are in conformity with finding [6] who tested efficacy of 20 plant species and found all extracts decreased their efficacy against Pyricularia grisea an incitant of rice blast disease with increase in storage period. [7] It was observed that storage of different plant extracts viz. Garlic, Ginger, Darrek, Goat weed, Wild sage and Paracress decreased their efficacy in inhibiting the conidial germination of Eresiphe poligoni of Pea with increase in the storage period. [8] Researcher studied the effect of storage of Ginger, Adulsa, Goat weed, Indian pivet and Wild sage at 15\% concentration on the percent growth inhibition of Alternaria porri causing Purple blotch of multiplier Onion and found that their efficacy in inhibiting the growth of $A$. porri decreased with increased in the storage period. However, in case of natural product i.e., MPG maximum radial growth of test fungus mycelium ( $57.33 \mathrm{~mm}$ ) was observed at 0 day storage period and radial growth of mycelium gradually decreased with increase in storage period and minimum radial growth of $42.50 \mathrm{~mm}$ was recorded at 10 days of storage period. In other words its effectiveness in inhibiting the growth of $F$. oxysporum increased with increase in storage period.

The results in Table 4 indicated that all the plant extracts showed decrease in their efficacy in inhibiting the mycelia growth of $F$. oxysporum with increase in storage period. Garlic extracts was found to have 100 per cent inhibition of fungal growth over Control at 0 day of storage whereas at 2, 4, 6, 8 and 10 days of storage it is 88.88, 75.55, 62.96, 50.00 and 41.66 per cent respectively over the untreated control. The decrease in the effectiveness of botanical extracts when stored for longer period might be due to changes in the chemical constituents of botanical extracts when kept for longer period or it might be due to deterioration or depletion of the constituents or might be due to the unstable or volatile 
nature of the botanical extracts during storage. However, in case of MPG its growth inhibition per cent increase with increase in storage period over control. The increase in the effectiveness of MPG when stored for longer period might be due to complete fermentation of mixture which might have released enough potential chemical compounds toxic to the pathogens.

\section{Conclusion}

In the present investigation storage of botanical extracts reduced the effectiveness on the radial growth of Fusarium oxysporum but got enhanced in the case of Modified Panchagavya (MPG). Garlic extract showed no growth at 0 days of storage but in MPG maximum radial growth of fungal mycelium was observed at 0 day storage period and gradually decreased with increase in storage time over the untreated control. This study will be of great use to the Farmers and scientific community.

\section{Compliance with ethical standards}

\section{Acknowledgments}

The authors are thankful to ICAR and KVK for providing Funds for doing the study.

\section{Disclosure of conflict of interest}

Both the authors have contributed in the study and has interest in getting the manuscript published and has no conflict among each other.

\section{References}

[1] Sarhan ART, Sharif FM. Integrated control of Fusarium wilt of pepper. Acta Phytopathologic Entomologica Hungria. 1986; 21(12): 123-126.

[2] Reddy HR, Padmodaya B. Test to control the Fusarium wilt disease of tomato with various formulations show that Panchagavya (MPG-3) is the most effective. Down to Earth. 30 Sept. 1996.

[3] Jahangirdar S, Siddaramaiah AL, Ramaswamy GR. Influence of biocontrol agents and MPG-3 on Fusarium oxysporum f. sp. Cubense incitant of Panama disease of banana. Pl. Dis. Res. 2001; 16(1): 68-72.

[4] Sharvelle EG. The nature and uses of modern fungicides, Burgess Publ. Co. Minn; USA. 1960; 308.

[5] Vincent JM. Distortion of fungal hyphae in presence of certain inhibitors. Nature. 1927; $159: 850$.

[6] Kamalakannan A, Shanmugan J Surendran M, Srinivasan Q. Evaluation of plant extracts against Pyricularia grisea causing rice blast. Ann. Pl. Protec. Sci. 2001; 9(1): 68-72.

[7] Tabin T. Influence of plant extracts on Powdery mildew (Erysiphe polygoni D.C.) of Pea cv. Makhyatmubee in Manipur, M.Sc. (Agri.) Thesis submitted to Central Agricultural University, Imphal. 2005; 22-24.

[8] Huidrom S. Influence of plant extracts on Purple blotch of Multiplier onion (Aliumcepa L. Aggregatum Don). M.Sc. (Agri.) Thesis submitted to Central Agricultural University, Imphal. 2006; 43-44. 